\title{
Changing Insight to the History of Transplant Surgery
}

\author{
Elena Usova
}

International Association of Surgeons, Gastroenterologists and Oncologists, Honorary Member

\author{
Corresponding author: \\ Elena Usova, MD, PhD \\ International Association of \\ Surgeons, Gastroenterologists \\ and Oncologists \\ Honorary Member \\ E-mail: lenulya2510@gmail.com
}

Most of the papers focusing on the history of transplant (Tx) surgery point to Joseph Murray as a surgeon who has performed the first successful human kidney allotransplant in 1954. Later on in 1990, he was awarded the Nobel Prize shared with other scientists. However very few papers mention physician who did this surgery first in 1933, as well as successful case series in 1940s. This article is presumed to clear this up.

Key words: first human allotransplant, kidney transplantation

\section{INTRODUCTION}

Nowadays organ Tx has become a standard of care for many previously deadly diseases, e.g. kidney Tx for end-stage kidney disease. According to OPTN (Organ Procurement and Transplantation Network) as for January $1^{\text {st }}$, 2020 (day of this manuscript writing), on average, 95 Tx take place each day in the United States which includes 11 different organ types (1). Given the data presented, 21,314 kidney Tx plus 811 combined kidney/pancreas Tx have been performed in 2019. In total, starting from 1988, these numbers are 467,673 and 24,557, respectively (1). Almost every author of the manuscript on kidney Tx surgery mentions Joseph Murray as a first physician who succeeded in human kidney allotransplant. That would in no way be detrimental to his role of the pioneer of successful living donor transplantation. But at the same time, there is no data available about Ukrainian surgeon Yuriy Voronoy who did the first successful human kidney allotransplant series before and published his experience in 1950. Even though some papers mention his first unsuccessful in regard to patient's postoperative death, but first done human allotransplant from 1933. Detailed review of the original Voronoy's manuscripts gives a completely another idea on this issue. Before that, there is a need to mention that the first patient has been dialyzed in 1943, and first successful clinical use of dialysis took place in September 1945 in Netherlands becoming available for common clinical use in 1950s (2,3). Its first clinical use in USSR starts just from 1958 (4).

\section{First human kidney allotransplant}

The first human kidney allotransplant has been done by Dr. Y. Voronoy on
Received: 28.01.2020 Accepted: 20.02.2020

Copyright (c) Celsius Publishing House www.sgo-iasgo.com 
April 3rd, 1933 and published in 1934 (fig. 1) (5). In introduction author refers to specific complementbinding antibodies as a cause of graft rejection acknowledging there is a need for their blockage. He guessed mercury chloride could be the agent capable for blockage of immunologic organs (e.g. spleen, lymph nodes, liver, etc.). It was the widespread one for suicide that time so its poisoning was considered to be the strong indication for kidney Tx like dialysis in high toxicity levels is nowadays. He described the spleen microscopy in his paper as following: "Spleen pattern lacks the typical follicles. On the background of markedly thinning out follicles there can be observed the increase of adenoid substance of the spleen. As for reticulo-endothelial mesh, it is sparse, cells are degenerated and do not demonstrate cell division. Among reticular tissue, there is a big amount of erythrocytes on different stages of breakdown and looking as amorphous yellowish-brown pigment. Venous sinuses lost their form and are filled up with erythrocytes. There are quite large thin-wall hyperemic vessels in the spleen parenchyma. Large sclerotic trabeculae penetrate the specimen" (fig. 2).

Dr. Y. Voronoy was considering living donor $T x$ an unethical procedure as potentially harming the healthy individual. This is the reason why he did the deceased donor Tx only to his patients.

For better understanding here are the key points of his first case report: "Patient B., a 26-year-old female, was admitted to the hospital on March 31st for mercury chloride poisoning of about 24 hours duration. When attempting suicide she swallowed 4 grams of mercury chloride. Patient admits that right upon the ingestion she experienced acute stabbing pain and vomiting. She currently complains of spastic abdominal and lower back pain, is constantly vomiting with bile-staining masses. She has prominent stomatitis, occasional muscular fasciculations, and pallor. Her pupils are symmetric and reactive to light, reflexes are $2+$. Her consciousness is alternating accompanied by pain and seizures. She experiences anuria with no urine discharge even upon catheterization. Pulses are $2+, 60-70 /$ minute. Body temperature is within normal limits. Complete blood count shows poikilocytosis, polychromatophylia, leukocytosis with left shift, anemia". As seen above, patient had an absolute indication for kidney Tx like she would for dialysis nowadays.

After follow-up, on April 3rd patient still remains anuric. The donor was a 60 -year-old male with fracture of skull base with no clinical and laboratory signs of infection. The donor blood type was B (III), recipient one was 0 (I). Thus, this surgery has become not only

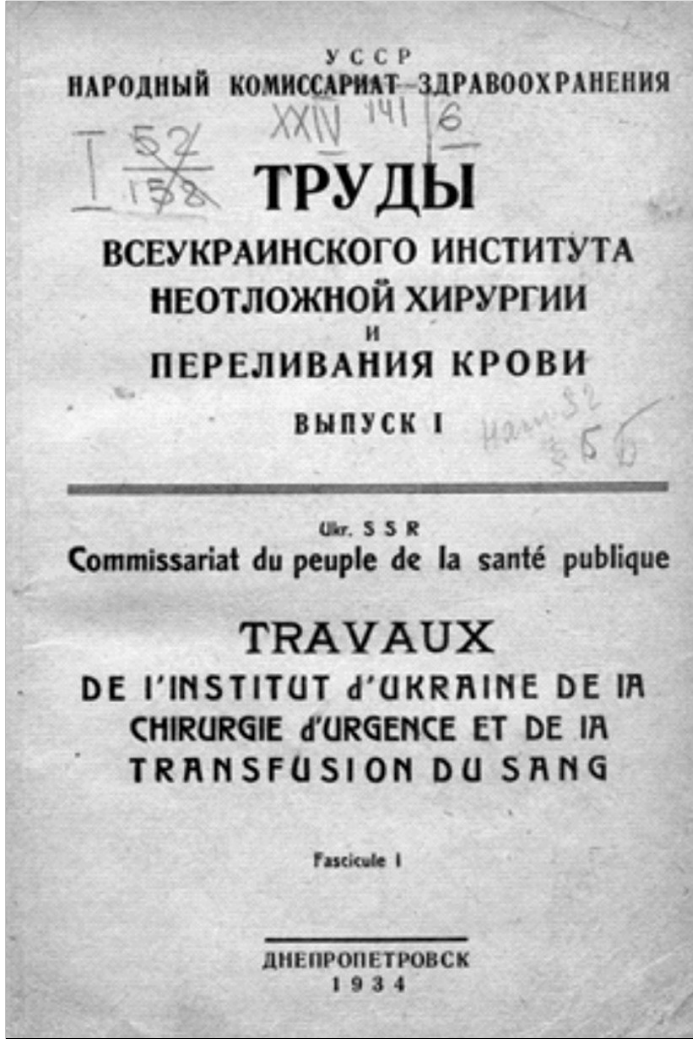

Figure 1 - Title page of hardback collection with Voronoy's original manuscript on human first kidney Tx

the first human organ allotransplant, but first ABOincompatible one as well. Surgery has been done the same day. Kidney was transplanted to the anteromedial aspect of the right middle thigh under the local anesthesia with Novocaine solution using femoral vein and artery after 6 hours of donor warm-ischemia time (WIT) - taken from deceased donor 6 hours after his death (fig. 3). Nowadays this is well known that WIT greater than 60 minutes is associated with significantly

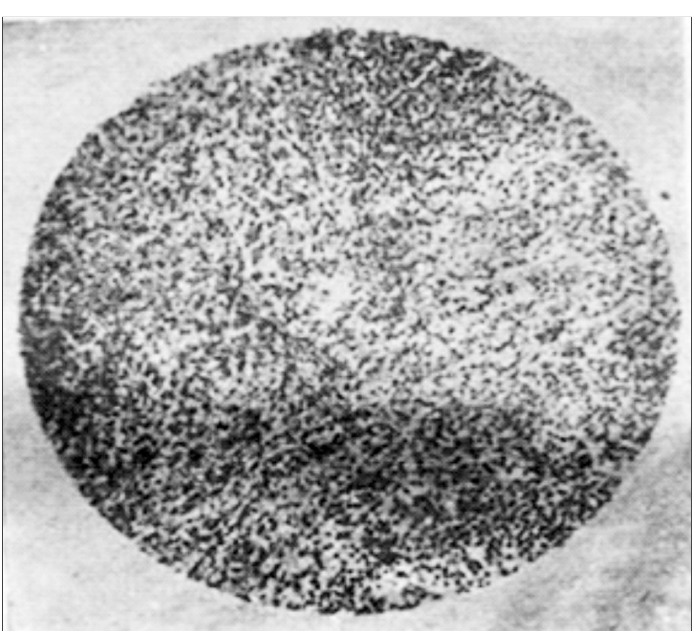

Figure 2 - Microscopy of patient's spleen after mercury chloride poisoning. From Ref 5 


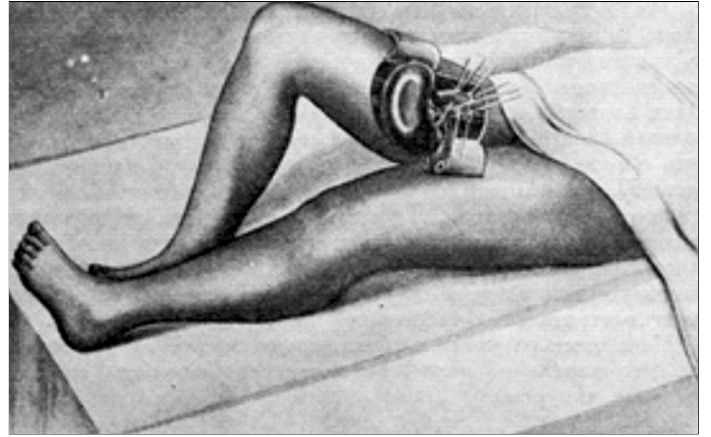

Figure 3 - Original picture of Voronoy's procedure of kidney Tx. From Ref 5 and Ref 10.

decreased long term graft survival however may last up to 200 minutes (6). More recent studies have shown a $<80$ minutes WIT might be acceptable to avoid graft failure (7). Kidney has not been washed out on the back table (5). Kidney and femoral vessels have been rejoined using modified Carrel suture. Ureterostomy has been done. Right upon vessels rejoining, urine discharge from ureter and its peristalsis as well as prominent pulsation of the renal vessels appeared.

On April $4^{\text {th }}$ vomiting and seizures dismissed, patient complains of thirst. Ureter peristalsis and discharge of clear urine have been present. The right leg blood supply was sufficient. 24 hours after kidney Tx there was observed 10-fold decrease of mercury blood level. At the end of postoperative day 1 transfusion of type 0 (I) blood has been done after phlebotomy. Right upon that, discharge of bloody urine, patient agitation, vomiting, and seizures occurred.

On April $5^{\text {th }}$ patient's clinical condition significantly deteriorated and dropping of "lacquer" bloody urine was seen. On urinalysis there were proteinuria, occasional leucocytes, Rouleaux formations of red blood cells (RBCs). The same day at $9.40 \mathrm{pm}$ patient died.

Pathology of the kidney graft showed slightly enlarged glomeruli (fig. 4). In occasional lumens inbetween those and capsule on its inner surface there were fibrinoid masses and segregate RBCs with spared shape. Vessels in glomeruli were enlarged and filled up with hypochromic but spared RBCs. There was epithelium desquamation, some nonoccluding mural thrombi within interstitial blood vessels. There was no cellular infiltration. Changes in patient's native kidneys resemble those in the transplanted one.

Given the case presentation above as well as its pathology, there is a high probability that patient developed acute hemolytic transfusion reaction/ transfusion mediated hyperacute graft rejection both of which represent the type 2 (cytotoxic) hypersensitivity reaction. Even though nowadays recipients are managed with immunosuppressive agents, blood transfusions are usually avoided in those patients because of the risk of acute graft rejection induced by blood transfusion reaction (8). Moreover, if recipient had previous pregnancies/ blood transfusions/ transplantations, he/ she should be tested for preformed antibodies reactive with allogeneic HLA molecules since they can mediate hyperacute graft rejection. Dr. Y. Voronoy also emphasized in his manuscript there was patient deterioration immediately following blood transfusion stating it should be avoided. He also said about retransplantation feasibility for those patients. Two years later Dr. Voronoy also published his case report in Siglo Med in Spanish (9).

\section{Case series with successful outcomes}

In 1950 Dr. Y. Voronoy published his experience of 5 kidney Tx (10). He refers to Pavlov's studies on reflexes. He explains improvement of patient's native kidneys by impact of reflex from transplanted one. Dr. Voronoy used deceased donor kidney grafts preserved for 12 to 28 days after their explantation. Before kidney Tx, repeated skin Tx from deceased donor grown in tissue culture was performed. Viscero-cortico-visceral reflex mediated by metabolic substances has been described here as a key point. Prolonged graft survival was not the goal of kidney Tx. The target time for graft survival was 2 to 7 days in order to allow patient's own kidneys to recover. In that manuscript Dr. Voronoy described in detail 2 of his 5 cases.

Clinical case 1. A 47-year-old female patient was admitted to the hospital on May 21st, 1949 being diagnosed with chronic kidney disease, myocardio-

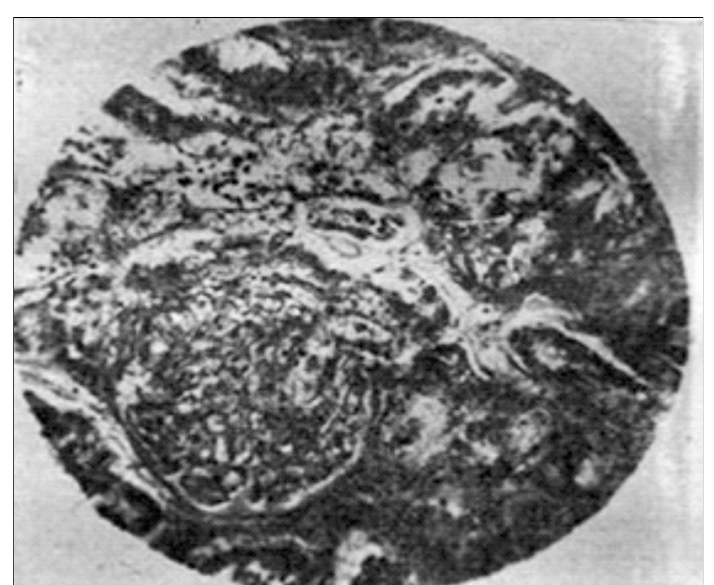

Figure 4 - Microscopy of kidney graft 48 hours after Tx. From Ref 5. 
dystrophy, and diffuse edema. The disease started on January $1^{\text {st }}, 1949$ and patient has been treated medically for 3 months. She was discharged home with improvement. However the edema started again soon. Patient did not get better even after treatment in urology unit. 3 weeks later edema has worsened and ascitis, polyserositis, and right sided hydrothorax occurred. Urinalysis of 24-hour urine showed aciduria, oliguria of 300-400cc with specific gravity of 1005, 4 grams of protein, leucocyturia with occasional RBCs and epithelial cells. Blood pressure was $175 / 115 \mathrm{mmHg}$. Clinical signs of pericarditis were present. Three consecutive cadaveric skin Tx to abdominal wall of the recipient have been done as a tissue therapy beginning from June $11^{\text {th }}$. There was no patient improvement. On July $5^{\text {th }}$ deceased donor kidney Tx has been done (kidney graft was preserved 24 days in advance). The donor was a 28-year-old male with skull trauma. There has been used the graft with 7 hours of donor WIT. The donor kidney has been transplanted to the left thigh using the same technique as above. Postoperative wound was locally splashed with 100,000 units of penicillin. Ureter peristalsis started immediately and was followed by urine secretion.

The next day edema has significantly decreased. There was obvious ureter peristalsis with yellow urine discharge from transplanted kidney. Upon urinary bladder catheterization $300 \mathrm{cc}$ of urine with specific gravity of 1020, protein of 1.5 grams, occasional RBCs, and no epithelial cells was obtained. 2 days after surgery the patient gets significantly better, edema and hydrothorax have resolved. Upon catheterization $350 \mathrm{cc}$ of urine with specific gravity of 1023 and 0.3 grams of protein was obtained. On postoperative day 4 , urine discharge from bladder was $1200 \mathrm{cc}$ per 24 hours with specific gravity of 1020 and protein of 0.099 . However urine secretion from transplanted kidney disappeared with no ureter peristalsis. Upon graft exploration thrombosis of its small vessels was observed. Transplanted kidney has been removed. Postoperative course was uneventful. Patient recovered completely and was discharged home 2 months later.

Clinical case 2. A 23-year-old female patient underwent left nephrectomy for tuberculosis infection. Later on patient developed right flank pain, pyuria, hematuria, and fever. The patient was admitted to urology unit on August 8th, 1949. Cystoscopy was not feasible. Intramuscular indigo carmine and oral methylene blue did not stain urine. Intravenous calcium chloride and glucose were injected. Fever was preceded by pyuria dismiss and increase of right flank pain. There was no bacteria in urine observed. There was no improvement in two months. After 3 consecutive skin graft $T x$, kidney $T x$ has been done on October $18^{\text {th }}$ (preserved 12 days in advance) taken from 25-year-old deceased female donor died from ectopic pregnancy with 8 hours of donor WIT. Surgical technique and management were the same as in the last case but blood transfusion of $200 \mathrm{cc}$ has been done. There was a prominent urine staining 5 minutes after indigo carmine injection. Body temperature normalized on postoperative day 8. Graft necrosis occurred 7 days later, and kidney graft has been removed. Patient recovered completely and was discharged home in 2 months.

\section{Dr. Y. Voronoy's life}

Dr. Y. Voronoy has graduated from the Medical school in Kyiv, Ukraine in 1921 (11). Upon graduation he started his scientific career at the same institution and moved to Kharkov in 1926, and to Kherson in 1931, respectively. In 1935 he was awarded a PhD degree without theses. During the World War II he was deported abroad. Upon his return back home, he was banned to teach. In 1944 he moved to Zhitomir and in 1944 to Kyiv were he headed unit of surgery. He passed away in 1961 and was buried in Kyiv (fig. 5).

\section{CONCLUSION}

The two endpoints of Tx surgery are patient survival and graft survival. In respect to that, organ retransplantation in case of graft failure becomes a method

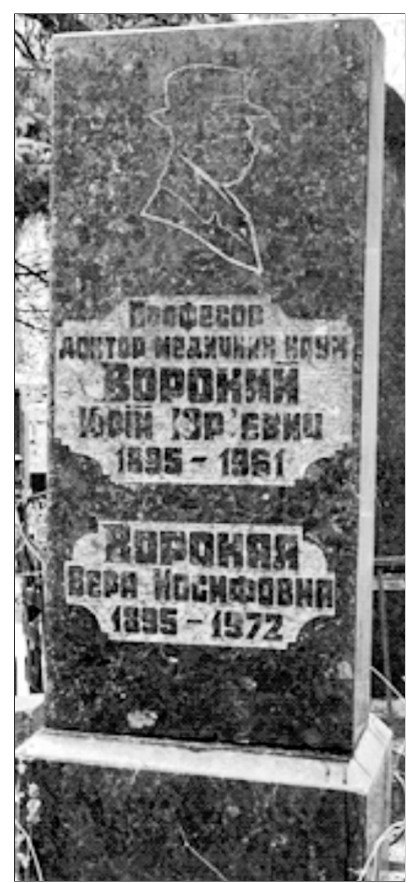
of choice. Taking into consideration the analysis of Y. Voronoy's manuscripts and absence of dialysis that time, recipient survival as an endpoint was successfully achieved in two patients to whom Dr. Y. Voronoy has done kidney Tx. Therefore human first deceased donor kidney allotransplant, the first AB 0-incompatible human organ $\mathrm{Tx}$, and eventually the first suc-

Figure 5 - Y. Voronoy's grave in Kyiv, Ukraine, January 2020. 
cessful kidney Tx in human fairly belong to Dr. Y. Voronoy.

\section{Conflict of interest}

\section{The author declares no conflict of interest.}

\section{REFERENCES}

1. Available from: https://optn.transplant.hrsa.gov/

2. Kolff WJ, Berk HTJ, Welle M, van der Ley AJW, van Dijk EC, van Noordwijk J. The Artificial Kidney: a dialyser with a great area. Acta Medica Scandinavica. 1944;117:121-34.

3. Gottschalk CW, Fellner SK. History of the science of dialysis. Am J Nephrol. 1997;17(3-4):289-98.

4. Лашутин СВ. История гемодиализа в России (лекция) Альманах клинической медицины. 2009;20:59-65. Russian

5. Вороной ЮЮ. К вопросу о блокаде ретикулоэн-дотелиального аппарата у человека при некоторых формах отравления сулемой и о свободной пересадки целой почки, взятой у трупа, как метода лечения анурии при этом отравлении. Труды Всеукраинского института неотложной хирургии и переливания крови. 1934;1:221-23. Russian
6. Vinson AJ, Rose C, Kiberd BA, Odutayo A, Kim SJ, Alwayn I, et al. Factors associated with prolonged warm ischemia time among deceased donor kidney transplant recipients. Transplant Direct. 2018;18;4(5):e342.

7. Chen J, Mikhail D, Sharma H, Hijazi A, Nap D, Stitt L, et al. Donor warm ischemic time $>80 \mathrm{~min}$ is an important predictor of kidney graft survival from donors after cardiac death. Am J Transplant (Internet). 2017;17(3). (about 2 p). Available from: https:// atcmeetingabstracts.com/abstract/donor-warm-ischemic-time80min-is-an-important-predictor-of-kidney-graft-survival-fromdonors-after-cardiac-death/. Accessed January 12, 2020.

8. Holt S, Donaldson H, Hazlehurst G, Varghese Z, Contreras M, Kingdon $\mathrm{E}$, et al. Acute transplant rejection induced by blood transfusion reaction to the Kidd blood group system. Nephrol Dial Transplant. 2004;19(9):2403-6.

9. Voronoy Y. Sobre el bloqueo del aparato reticulo-endothelial del hombre en algunas formas de intoxicacion por el sublimado y sobre la transplantacion del rinon cadaverico como metodo de tratamiento de la anuria consecutive a aquella intoxicacion. El Siglo Med. 1936:97:296. Spanish

10. Вороной ЮЮ. Пересадка консервированной трупной почки как метод биостимуляции при тяжелых нефритах. Врачебное дело. 1950;9:813-5. Russian

11. Available from: https://ru.wikipedia.org/wiki/Вороной,_Юрий_Юрьевич 